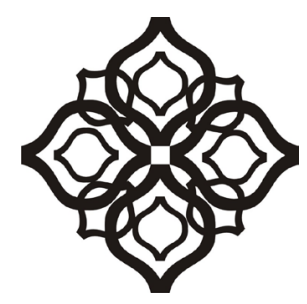

Shirkah

Journal of Economics and Business 


\section{Shirkah}

Journal of Economics and Business

Vol. 2, No. 2, May-August 2017

ISSN: 2503-4235 (p); 2503-4243 (e)

\section{Editor in Chief}

Sri Walyoto

\section{Editorial Boards}

Abu Umar Faruq Ahmad, UBD School of Business and Economics, Brunei Darussalam

Amelia Fauzia,

Asia Research Institute, National University of Singapore, Singapore

Cedomir Nestorovic,

ESSEC Business School Asia Pacific, Singapore

Dwi Condro Triono,

Faculty of Islamic Economics and Business, IAIN Surakarta, Indonesia

Fahmy Radhi,

Faculty of Economics and Business Universitas Gadjah Mada, Yogyakarta,

Indonesia

Hasan Basri,

Syiah Kuala University, Aceh, Indonesia

Johan Fischer,

Department of Social Sciences and Business Roskilde University, Denmark

Masudul Alam Choudhury,

Postgraduate Program in Islamic Economics and Finance, Trisakti University,

Jakarta, Indonesia and the College of Economics and Political Science (CEPS) in

Sultan Qaboos University (SQU), Oman

M. Falik Isbah,

School of Humanities and Social Science, University of New South Wales, Australia M. Ishaq Bhatti,

La Trobe Business School Department of Economics and Finance La Trobe

University, Australia

Najib Kailani,

Pascasarjana, Universitas Islam Negeri (UIN) Sunan Kalijaga, Yogyakarta, Indonesia 
Nunung Nurul Hidayah,

Aston Business School, Aston University, Birmingham, United Kingdom

Shaikh M Ghazanfar,

Departement of Economics, University of Idaho, Russian Federation

\section{Managing Editors}

Fitri Wulandari

Jasanta Perangin-angin

\section{Assistant to Editor}

M. Endy Saputro

M. Zainal Anwar

Supriyanto

Shirkah Journal of Economics and Business is a peer-reviewed journal published three times a year (January-April, May-August and September-December) by Faculty of Islamic Economics and Business, Institut Agama Islam Negeri (IAIN/ State Institute for Islamic Studies) Surakarta Central Java, Indonesia. The main objective of Shirkah is to offer an academic space of exchange ideas and initiate the increase number of qualified article produced by postgraduate students, practitioners and academicians.

\section{Editorial Office}

Ruang Jurnal Shirkah

Ground Floor, West Gate,

Faculty of Islamic Economics and Business

IAIN Surakarta

Jln. Pandawa No. 1, Kartasura, Sukoharjo, Jawa Tengah Kode Pos. 57168

Phone (+62271) 781516 Fax: (+62271)782336

E-mail: shirkahiainsurakarta@gmail.com

Website: http://shirkah.or.id/ 


\section{Shirkah}

Journal of Economics and Business

Vol. 2, No. 2, May-August 2017

ISSN: 2503-4235 (p); 2503-4243 (e)

\section{Table of Contents}

\section{Articles}

Shairil Izwan Taasim

Ramali Yusoff

An Instrument Developing Cashless in Malaysia

Aam S. Rusydiana

Irman Firmansyah

Efficiency versus Maqasid Sharia Index An Application on Indonesia

Islamic Bank

Azhar Ibrahim

The Call for Islamic Economics Shades of Contestation

Warsono

Deferred Tax Assets and Deferred Tax Expense Against Tax Planning Profit Management

Lisdawati Arifin

Earning on Response Coefficient in Automobile and Go Public

Companies

Farihatul Qamariyah

Waroeng Steak: Spritual Company in the Context of Post-Capitalism 


\title{
The Call for Islamic Economics Shades of Contestation
}

\author{
Azhar Ibrahim \\ Department of Malay Studies \\ National University of Singapore \\ mlsai@nus.edu.sg
}

"Let there arise out of you

A band of people

Inviting to all that is good

Enjoining what is right

And forbidding what is wrong."

(al-Quran, Ali Imran 3:104)

\begin{abstract}
This paper attempts to highlight some of the criticisms made against the ideas of Islamic economics. The discourse of Islamic economics is relatively recent, although its expression could be traced to more than five decades ago. Today there are countless discussions and affirmations for Islamic economics, coming from both experts in the area of economy and Islamic legal thought, apart from the many journalistic advocacy type that is enamored by the call for the establishment of Islamic economics, or at least the Islamic banking. While there is much celebration to this idea, the criticism against it is far less and hardly noticeable. To date, Timur Kuran and to some extent Nazih Ayubi have been vocal in highlighting the rhetorics and the insubstantiality of the idea of Islamic economics.
\end{abstract}

Keywords: Islamic economics, Islamic identity, sharia

\section{Introduction}

Generally, the idea of Islamic economics is accepted as pertinent, legitimate and most importantly compliant to the principles and spirit 
of Sharia. This general acceptance and fervor for Islamic economics is enhanced by the process of Islamisation in the social and cultural scene, and the rise of political Islam, alongside a more assertive affirmation for securing Islamic identity. The great enthusiasm to establish a distinctive Islamic institution that becomes an "alternative" to the conventional (read Western) model becomes almost the mantra amongst its Islamist advocates. While these advocacies for Islamic economics are still gaining momentum today, there is however a clear absence of counter discourses to seriously look at its propositions and justifications. Scholars like Timur Kuran obviously wrote many critical pieces on Islamic economics, but the discourse at the popular or public level is barely touched by those critical insights. It is not surprise that to making criticisms against the Islamic economics will risk the critics as trying to undermine Muslims system of beliefs or at least being ignorant of the Sharia's command in Muslims' life.

Basically the discourse of Islamic economics is characterized by three main features. First, it is non-diagnostic in outlook as the primary strategy is to advance a set of normative principles to be implemented and observed in the economic system. Its interest to affirm the Islamic model does not come with critical postures of its own limitations. Second, it is loaded with Islamic legal precepts and injunctions, focusing which items or transactions that are sanctioned in Islam or otherwise. Third, it is hardly grounded with the endogenous ideas and practices of the economy, and its proposals hardly take into considerations of the standard practices, with sheer ignorance of the local discourse of economics and development.

\section{The Fervor for Islamic Identity}

The euphoria for Islamic economic is very much an exclusive fervor for identity and not so much on the substantiality. The flagship of Islamic economics centers primarily on the need to avoid any dealings 
that involved riba (usury) which is prohibited in Islam, and that Islamic economics should be able to guarantee welfare via the institution of religious taxes called zakat. While Muslim reformers since late $19^{\text {th }}$ century have given critical interpretations of the idea of usury in banks' interest to mean largely referring to exploitations in the realms of economic life, the generally sentiment is still adhering to the dominant view that it is prohibited in Islam. With such views persisting in Muslim societies that could explain why there is so much support and enthusiasm for interest free Islamic banking (Ayubi, 1991; Listyaningsih, 2017; Arzayeva, 2017; Aboulaich, 2017)

Today the discourse on Islamic economic have evolved as research and teaching subject of its own (Boediman, 2017; Ahmad, 2017). Interestingly various religious writers often become expert of Islamic economics by virtue of their legalistic opinions, although their training in economics per se may be negligible. "Because Islamic economics was developed to serve cultural and political ends," noted Timur Kuran, "it did not have to meet scientific standards of coherence, precision, or realism." It needed only to differentiate itself from the intellectual traditions that it was aiming to displace (Dzutsati, 2016). Accordingly, contributions to Islamic economics typically begin by identifying the distinguishing characteristics of an Islamic economy. From Maududi to the present, the most fundamental of these characteristics has been the prohibition of interest. Two others have been zakat, which is an ancient redistribution system, and the requirement that economic decisions pass through an Islamic moral filter" (Kuran, 1995).

Hence little surprise that the discourse is marked by endless justification for Islamic economics in order to ensure that Islamic precepts are being observed, preventing Muslims from being tainted by the capitalistic sins of usury and other sinful related transactions. The primary 
concern on justifying Islamic economics is primarily religious and cultural, and not so much in addressing the economic matters of Muslims. When the idea was first promoted by the Islamist its moral-religious concerns was its main drive. Later on with the expansion of Muslims middle class and its commercial and trading class, the enthusiasm for Islamic economics expanded tremendously. The concerns for preserving an Islamic way of life, the authentic Islamic approach, free from secular and atheistic elements which have been the staple of the Islamists have become a commonplace. An observation by Kuran on this outlook is best described below:

A conviction gaining currency among contemporary social thinkers in the Muslim world is that healthy economic development entails subordination of all production, exchange, and consumption decisions to the behavioral norms of Islam. The economic woes of Muslim countries, many scholars contend are due in large measure to departures from Islamic codes of conduct: if only the individual Muslim had not abandoned the norms prescribed by his religion and succumbed to his greed for material gain, Muslim society would be free of the backwardness, poverty and inequality which characterize it today. The doctrine of economics put forth by these scholars, which is at once a reflection of public opinion and a powerful force shaping it, has considerable influence on economic behavior throughout the Muslim world. An analysis of the assumptions and arguments that underlie the Islamic doctrine can therefore enhance our understanding of the economic problems facing Muslim countries (Kuran, 1983).

The utopian postures of Islamic economics demands and imagined something form Islamic classical past as the answers for the present day economic challenges. This naivety is at the same time utopian, to think that the Islamic systems can correct the excesses of capitalism, when the system itself becomes more or less an appendage to the capitalist order with a pious garb of Islamic symbolism. Thus it is apt when Kuran noted 
that "Islamic economics did not emerge from a drive to correct economic imbalances, injustices or inequalities" (Kuran, 1995). Elsewhere he adds:

Neither individually nor collectively have the economic measures taken in the name of Islam revolutionized the economies they were supposed to cleanse and perfect. This is hardly surprising when one considers that they were inspired by cultural goals rather than efforts to stimulate economic development. In any case, whatever the economic successes of Islamic history, it is patiently unrealistic to expect the Qur'an or early Islamic precedents to yield the blueprint for contemporary economic life. A modern economy is far more complex than the seventh-century Arabian desert economy that contemporary Islamists treat as their model. The inspiration for economic development must come primarily from outside Islam and Islamic precedents (Kuran, 2005)

Kuran further adds that those who advocate Islamic economics, in their discourse with so much space given to justify the authenticity of their system, hardly give space in addressing pertinent economic issues:

"Equally revealing is the content of Islamic economics. Few contributions to the literature have focused on solving pressing economic problems. Their emphasis has tended to be on establishing distinctly and self-consciously Islamic approach to economics. The typical text combs traditional Islamic sources for prescriptions that will differentiate Islamic economics from more established economic doctrines. The blanket prohibition of interest ostensibly found in the Koran quickly became the centrepiece of Islamic economics precisely because interest not only plays an important role in every contemporary doctrine and is essential to economic life almost everywhere. By favouring a ban on all interest, regardless of from and level, Islamic economics can claim that the deposit-taking and lending operations of "Islamic banks" differ fundamentally from those of conventional banks (Kuran, 1996). 
With its extrication of the fiqh/legal formulations for Islamic economics, the intellectual or discursive energy spent on endless clamor, with an exclusive tone that the Islamic system would ensure Muslims to observe the religious command completely, alongside other Islamic systems, be it in the forms of education, health and recreation, arts and culture, politics, and general lifestyle.

\section{Islamic Economic, Its Origin}

It has it recent origin in the post-war period although in the discourse it is not uncommon that texts and nomenclatures from the classical Islam past was invoked. Kuran insists that we could only understand this euphoria of Islamic economics if we trace its historical roots when Muslims in the sub-continent Indian were insistent an exclusive political, social and economy system in order to remain authentically Muslims. The attraction to Islamic economics, especially amongst the Muslim audience, in particular from the middle class in the urban centres are characterized by its moral-panic or moralism that the present order are corrupt, sinful and undermine Muslims' akidah and wellbeing (Gouda, 2016; Buehler, 2016). As Kuran points out:

Islamic economists never tire of pointing out that contemporary Muslim communities are rife with greed, corruption, dishonesty, deceit, and exploitation. It is true that phenomena such as rentseeking and opportunism are distressingly common in South Asia, the Middle East and North Africa. It is also true that most Muslim communities feature sharp inequalities. But the problems will not disappear merely through praises of Islamic virtue. In the absence of institutional reforms that make socially undesirable behaviors more costly (improvements in the legal system, industrial standardization, and removal of anti-competitive regulations) the problems of opportunism and rent-seeking will persist. Moreover, the main effect of turning the spotlight on these problems will 
be to make Muslims ever more conscious of their moral failings. Guilt-ridden, they will seek to compensate for their moral deficiencies through greater outward piety (Kuran, 1996)

But it is not sufficient that to explain the emergence and the popularity of Islamic economics is due to the increasing religious fervor amongst Muslims, where the Islamic identity becomes a central concern. Kuran again explains: "That concerns over identity account for the emergence of Islamic economics does not mean, of course, that these fully account for its subsequent evolution. Once the doctrine had been outlined, various actors found it a convenient vehicle for advancing political and economic aims unrelated to identity." (Kuran, 1997)

While Kuran often linked the origin of Islamic economics from the clamor of Indian Muslims revivalists such Maududi, he nevertheless noted the dynamics of the rise of Saudi petro-dollars

A milestone in the evolution of Islamic economics was reached with the Arab oil boom of the 1970s. Led by Saudi Arabia, the boom's major Arab beneficiaries felt obliged to step up their support for Pan-Arab and pan-Islamic movements, and Islamic economics was among the causes that received vast assistance. Accordingly, the first Islamic commercial banks started operation in 1975, as did the Islamic Development Bank, established to transfer petrodollars to predominantly Muslim developing countries through interest-free instruments. The period of the oil boom saw also the enhancement of the institutional infrastructure of Islamic economics (Kuran, 1997).

Similar point is made by Ayubi when he questioned why there is a proliferation of Islamic banks. While some linked it to the increasing Islamicity amongst the population and even the government, Ayubi contends that "although a certain element of Islamic symbolism is involved, the expansion of Islamic banks has initially represented part of 
the general phenomenon of an ascendant pax Saudiana within the Middle East. Increasingly however, the expansion is becoming more specifically representative of the rise of a native commercial bourgeoisie in the Arab world" (Ayubi, 1991). While some writers tend to conclude that the rise of Islamic economics as an expression of the process in which the Islamists attempt to capture power or to be a dominant force in Muslim society, Ayubi would see otherwise. Islamists or Islamic organisations he noted have not established Islamic enterprises in large scale, or aimed to gains some dominancy in the economy. Instead the interest on Islamic economic lies in the hand of

The rising native mercantile bourgeoisie that has stretched its hand to Islamic movement in order to impart to itself a certain element of religious legitimacy. In doing this, the mercantile bourgeoisie seems more often to have sought help from the more traditional and conservative segments of the Islamic movement. It is quite possible, of course, that the two forces will coalesce at some stage, but I think that the moving force behind such a process is more likely to be the mercantile bourgeoisie than the Islamic movement. If the 'Islamic' enterprises are now to be found organically linked to any other social forces, it is not really to the Islamic movement that they are tied but rather to the broader class of the 'lumpen' commercial bourgeoisie. If the Islamic movement and the bourgeoisie seem to overlap at certain points, this is basically because of their shared hostility to the State Establishment. But unlike many radical Islamists, the owners of the so-called Islamic companies are prepared, for their own materialist purposes, to ally themselves with elements in the State apparatus and the official and non-official press. Indeed the Islamic companies have co-opted a number of influential political figures (including ex-ministers and governors) and outspoken editors and journalists (including some in the opposition press), and some of these co-opted figures are far from being sympathetic to the radical Islamic movements (Ayubi, 1991) 


\section{Celebrating and Championing Islamic Economics}

In sum, Islamic Economics has been much celebrated too, but an intellectual scrutiny of its proposition is not common, in comparison to those that analyze the fundamentals and workings of the Islamic economics, without problematizing some of its inherent limitations and rhetorics. The discourse on Islamic economics seems to open the gate where almost everyone can deliberate about it, some with pietistic pretension to clamor it as part of an Islamic struggle, often garbing their exposition in the name of "Islamic perspectives."

One of the most repeated claims will be on the efficacy of the zakat instrument in order to ensure the wellbeing of Muslims, where the well to do Muslims helpings those needy ones. Often claims made that through such instruments Islam has given the thought on redistribution of wealth in society, although the dynamics of this instrument is hardly given scrutiny. In the Islamic creed, the payment of Zakat is part of the religious obligations of Muslims. To the proponents of Islamic economy, the zakat mechanism is not only to ensure that God's command is obeyed but also in ensuring. However, how far zakat can really ensure the redistribution of wealth in society, a point that many proponents of Islamic economics tend to belief. It is the task of a critical research to expose the illusion and claims of 'the Islamic economists' apparent belief that the Islamic injunctions would guarantee economic justice (Kuran, 1986: 178).

The purpose of Zakat as we have seen, is to promote equality by redistributing wealth from the haves to the have-nots. It is by no means self-evident, however, that zakat would achieve this purpose. Since it entails taxing only some categories of income and wealth, and then at various rates, its distributional impact would depend on the composition of society's output. Its narrow version places the burden of taxation entirely on categories of income and wealth known in the early years of Islam, notably 
agriculture, mining, and precious metals. With industrialization and the explosion of the service sector, these sources of income and wealth have dwindled in importance, even in the least developed countries. Also, most of the poor households in today's world are concentrated in agriculture, and most of the rich outside agriculture. It is not clear, therefore, that zakat would promote equality; it might well promote inequality. This conjecture is supported by a study of one of the narrow zakat schemes in existence. What about the broader schemes that have been proposed? It is certainly possible that they would play an equalizing role, although this remains to be demonstrated. The impact of any particular scheme will depend on the characteristics of the economy to which it is applied. A scheme that serves as a strong equalizer in a contemporary economy dominated by industry and agriculture could lose its potency as services for which rates have not been specified gain in importance (Kuran, 1986: 176-177).

Again Kuran points it clearly: "Although some Islamic economists have touted zakat as an unmatched instrument for inequality reduction, none of the official zakat systems has put a significant dent in poverty." (Kuran, 1995: 163-164) In sum, the real motivations on embarking an Islamic economic system cannot be simply reduced to either due to the increasing religious affiliations amongst Muslim public or the economic urge for the optimization of the market to reap the significant portion of Muslim market. Perhaps the explanation could be found in both spectrums. Interestingly it could be said that as a proposition (albeit its pious undertone), a great number of Muslim populations are actually less concerned as to whether the economy is to be labeled as Islamic or otherwise as their concern is basically a viable and functioning economic system that can fulfill their bread and butter issues.

\section{Islamic Economics in Academia}

Today there are many centers of learning that offer courses on Islamic economy/ Islamic banking with the primary focus of mastering 
its structures and dynamics with the overall aim to prepare graduates and researches to reap the opportunities offered in this newly emerging sector. Interestingly too the mainstream economic structures "welcome" without much resistance, in comparison to its aversion to any kind of "socialistic" economy that aims to depart from the mainstream capitalistic economy.

The formation of Islamic banks subsequently requires "intellectual support" or enticing academic institutions to pay attention to its operation and potentialities, where its academic presence, bestows certain image of efficacy:

New institutes of Islamic economics came into being, and departments of Islamic economics were started in various parts of the Islamic world. Also, journals of Islamic economics began publication, and well-funded international conferences of Islamic economics became a regular occurrence. Once Islamic economics acquired the trappings of an academic discipline, it gained new complexities. Researchers steeped in Islamic economics went looking for new problems to address, and various applications of Islamic economic principles, including Islamic redistribution and Islamic banking, stimulated new debates. To this day, however, Islamic economics has remained preoccupied with defining the modern Muslim identity. One cannot make sense, therefore, of either contemporary Islamic economic thought or the current applications of Islamic economics without paying attention to the factors that stimulated its genesis half a century ago. The major stimulus to the emergence of Islamic economics was the perception of Mawdudi and his political associates that the IndoMuslim community was losing its identity (Kuran, 1997: 327329).

In one way the enthusiasm on Islamic economics is obviously a good sign in which Muslims take serious attention on building their economy and development. It is quite common that we come across the assertion of the need of an Islamic economic or Islamic banking, based 
on fulfilling the religious command, that all aspects of life, including economic transactions must be freed from unIslamic practices and ideas. As observed by Kuran:

For many proponents of Islamic banking, its religious rationale is far more important than its economic justification. Indeed, some respond to criticisms of the methods of Islamic banking by saying that its economic merits are secondary to its contribution to the revival of Islam. For them, the overriding objectives are the reassertion of Muslim identity, the reaffirmation of Islam's relevance to the modern world, and the restoration of Islamic authority. Islamic banking defies the separation between economics and religion. It invokes religious authority in a domain that modern civilization has secularized. Moreover, by promoting the distinctness of Islamic economic behaviour, it counters the absorption of Islamic civilization into western civilization (Kuran, 2010).

The discourse Islamic economics buttressed by Islamic doctrine has huge number of advocates, both within and without the academia, although divergent of views are not uncommon (Kuran, 1983: 357). Kuran noted various contending viewpoints on the exposition of Islamic economics:

At one end of the spectrum are the fundamentalists who seek literally to return to the perceived simplicity of the Arabian economy during Islam's early years. The fundamentalists efforts are directed solely at discovering the model of that ideal economy. Fully convinced that nothing needs to be added to the model, they are strongly resistant to the scientific spirit and to crosscultural exchange ideas and institutions. At the other end are the reformers, who seek to create a new economic system which, while being consistent with the spirit of the Koran and the Sunna, is not unchangeable. Recognizing that there are some areas where the Koran does not legislate, they believe that there should always be scope for reinterpretation. Muslims of every generation must, according to them, exercise independent judgment (ijtihad) to 
revise economic institutions. The reformers condone assimilation and imitation of non-Muslim institutions that do not violate fundamental Islamic principles. In between the extremes are those writers, by far the majority, who cannot be adequately classified because they appear as ardent reformers in one passage and as relentless fundamentalists in the norm. Given the diversity, there is inevitable injustice in any attempt to treat the Islamic literature as a uniform body of thought. Nevertheless, because all proponents of the Islamic doctrine are united in the belief that behavioral norms are at the center of Islamic system, it is appropriate to speak of a single doctrine-provided one zeeps in mind that the doctrine has many variants as proponents (Kuran, 1983: 357-358).

This brings us to the question is whether the advocate of Islamic economic are really propelled to address economic issues or to maintain a system away from the secular Western model. This in turn warrants us to evaluate as to whether there is such a link between Islamic banking and Islamism. Kuran is in the opinion that:

"The link between Islamic banking and Islamism is anything but imaginary. The founders and executives of Islamic banks see themselves as contributing to the reestablishment of the primacy of Islam in the lives of Muslims. Some want the entire social order restructured according to Islamic criteria, not only economic relations but also gender roles, education, the mass media, government, and much else. An appliance manufacturer might launch a new line of refrigerators or enlarge his workforce without intending to change the basic framework of the economy, to say nothing of revising the high school curriculum or reordering male-female relations. By contrast, Islamic bankers commonly view themselves as both profit seekers and agents of social renewal. They do not ask merely to be left alone, to be permitted to withdraw from the economic mainstream. They want to be noticed and to inspire. They wish to make their preferred 
financial practices the norm. They consider themselves in the vanguard of a struggle to cleanse the economy, indeed the whole social system, of harmful secular influences. The vast literature that falls under the rubric of "Islamic economics" confirms that Islamic banks are meant to serve a broad social mission. The literature holds that the prevailing capitalist and socialist economies generate injustice, corruption, inequality, poverty, and discontent. A major source of all these problems is interest, which pushes distressed borrowers into poverty, allows lenders to make risk-free gains without exerting any effort, and weakens social ties. By offering an alternative to interest, Islamic banking will contribute, so claims Islamic economics, to making the economy fairer, more egalitarian, and less harmful to the social fabric. But the objective is not simply to make Islamic banking more accessible. It is to make all banking Islamic (Kuran, 2010).

\section{The Limitation of Islamic Economics}

In the discourse of Islamic economics, we can obviously note the lengthy justifications on the Islamic approach in the economic transactions so much so the discussion is not unlike the pious tracts that exhort religious commitment and observance (Ebrahim, 2016) (Salehin, 2016). Not uncommon that the sermonic type of proposition elaborated many concepts from within the Islamic corpus, often linkages made that are weak, ambiguous and untenable, or even unpractical to be observed. Indeed, the discourse is marked by many subjects which has very little relevance for modern society, reflecting a thinking that is not able to relate to its present contexts. As Kuran noted: "Barter rules, the right of slaves, and transactions that any $20^{\text {th }}$-century reader will consider quaint make prominent appearances in contributions to Islamic economics, simply because they receive broad coverage in classical Islamic sources. At the same time, Islamic economics has contributed little to economic issues of great relevance to modern living (Ebrahim, 2016). 
In a way, the proponents of Islamic economics are right in pointing out the importance of the normative aspects, specifically behavioral norms. But in the context where these norms are understood in ahistorical and a sociological manner, then its limitation becomes obvious:

The Islamic doctrine captures an element of reality when it ascribes an important role to behavioral norms in the economic system it envisages. This is commendable, particularly since mainstream neoclassical economic theory, which constitutes the backbone of policy discussions in much of the world, pays almost no attention to norms. Indeed, there is little in the neoclassical literature to indicate that behavioral norms - in the form of moral codes, religious injunctions and ideologies — are used to reduce the costs of enforcing constraints on economic behavior in actual economies. But the principal strength of the Islamic doctrine is also its most glaring weakness. For the normative system of Islam is expected to provide perfectly well-defined and clear constraints on individual economic decisions and to be applicable with equal force to all societies in all stages of development. These factors, as we shall see, open the Islamic doctrine to criticism on at least two grounds. The first basis is that the doctrine takes no account of the finding of modern social science that as society expands norms become less effective as a means of achieving social cooperation and coordination. The loss in effectiveness, which results from an increasing frequency of violations, causes society to discard some norms and supplement or replace others with written laws and rules. For instance, norms requiring individuals to engage in charitable activities are supplemented as society grows by mandatory taxes designed to guarantee the transfer of some resources to the poor (Kuran, 1986: 356).

After so much discussion on the Islamic economics and its claim of representing an authentic Islamic version, often with the support from the Islamists movement/congregation and religious establishment, one cannot afford to ignore the obvious affiliation, alignment and even 
collusion of political Islam with the mainstream capitalistic order. While secular Western system was bitterly attacked, the domain of capitalistic structures remained relatively "untouched". It does make sense when Timur Kuran concludes this: "The main purpose of Islamic economics is not to improve economic performance. Notwithstanding the claim that Islamic economics provides a superior alternative to the secular economic doctrines of our time, its real purpose is to help prevent Muslims from assimilating into the emerging global culture whose core elements have a Western pedigree. Moreover, in pursuing cultural protectionism Islamic economics depends minimally on controlling the way Muslims behave in the marketplace” (Kuran, 1996: 438).

But there is an interesting twist here, the puritanical postures, that aimed at cleansing Islamic practices from unIslamic element, at the core, we cannot see a consistent stand; while dismissing the Western/secular practices as undermining Islam and the lives of Muslims, and the practices of Islamic economics is imperative to maintain Muslim's faith and religious practices, we hardly see the political/cultural Islamists shunning overtly from the mainstream capitalist system. Samir Amin saw the presence of political Islamism makes present in the cultural sphere in order to maintain an hegemonic grip over the thinking and practices of the people, or to be precise "The ritual assertion of membership in the community is their exclusive preoccupation," In society ridden by economic problems and structures, the Islamists generally were absent, as they see very little importance, with the exception of establishing schools and health clinics. On this basis, every current of political Islam chooses to conduct its struggle on the terrain of culture-but "culture" reduced in actual fact to the conventional affirmation of belonging to a particular religion. In reality, the militants of political Islam are not truly interested in discussing the dogmas that form religion. The ritual assertion of membership in the 
community is their exclusive preoccupation. Such a vision of the modern world is not only distressing because of the immense emptiness of thought that it conceals, but it also justifies imperialism's strategy of substituting a so-called conflict of cultures for the one between the imperialist center and the dominated peripheries. The exclusive emphasis on culture allows political Islam to eliminate from every sphere of life the real social confrontations between the working classes and the global capitalist system that oppresses and exploits them. "However, these are nothing but works of charity and means for indoctrination. They are not means of support for the struggles of the working classes against the system responsible for their poverty.". What is most apparent in Amin's observation is the alignment of the Islamism with capitalism itself:

"On the terrain of the real social issues, political Islam aligns itself with the camp of dependent capitalism and dominant imperialism. It defends the principle of the scared character of property and legitimizes inequality and all the requirements of capitalist reproduction. The support by the Muslim Brotherhood in the Egyptian parliament for the recent reactionary laws that reinforce the rights of property owners to the detriment of the rights of tenant farmers (the majority of the small peasantry) is but one example among hundreds of others. There is no example of even one reactionary law promoted in any Muslim state to which the Islamist movements are opposed. Moreover, such laws are promulgated with the agreement of the leaders of the imperialist system. Political Islam is not anti-imperialist, even if its militants think otherwise. It is an invaluable ally for imperialism and the latter knows it. It is easy to understand, then, that political Islam has always counted in its rank the ruling classes of Saudi Arabia and Pakistan. Moreover, these classes were among its most active promoters from the very beginning. The local comprador bourgeoisies, the nouveaux riches, beneficiaries of current 
imperialist globalization, generously support political Islam. The latter has renounced an anti-imperialist perspective and substituted for it an antiWestern (almost anti-Christian) position, which only leads the societies concerned into an impasse and hence does not form an obstacle to the deployment of imperialist control over the world system (Amin, 2008: 84).

\section{Critical Indonesian Responses}

It will be interesting to note the idea and responses in Indonesian on Islamic economics. Sjafruddin Prawiranegara, an Indonesian statesman and intellectual, had defined what is Islamic economics, insisting that an exclusive category or definition of Islamic economics is untenable. He insisted: "Dalam soal ekonomi tidak ada perbedaan antara ekonomi Islam dengan ekonomi bukan Islam, sebab ilmu ekonomi, dimana saja, kapan saja, dan pada siapa saja tujuan atau motifnya adalah: mencari hasil yang sebesar-besarnya dengan tenaga atau biaya yang sekecil-kecilnya" (Prawiranegara, 1988: 397).

Sjafruddin, like many Muslim intellectuals are generally convinced that if Islamic teachings are correctly understood and practiced, applied in the realms of economy, could ensure the wellbeing of Muslims. "Kalau kita perhatikan konsep-konsep atau sistim-sistim ekonomi yang dilaksanakan (dioperasikan) di dunia ini sebagai akibat sesuatu agama atau ideologi yang dianut oleh orang-orang atau golongan yang menjalankan usaha ekonomi itu, maka ternyata bahwa usaha ekonomi Islam-kalau sungguh-sungguh dilaksanakan berdasarkan ajaran-ajaran Islam sebagaimana terdapat dalam Al-Qur'an dan Hadis-adalah ekonomi yang paling cocok untuk memelihara alam ini sebagai tempat hidup manusia" (Prawiranegara, 1988: 406).

However, while other Muslim intellectuals were busy constructing what constitutes Islamic economics, Sjafruddin was more concerned on 
how the universal Islamic values can be put into practice in the economic development. In fact, he was concern on how the effects of unrestrained developed, that is ill-informed on the responsibilities and commitment as enjoined in the Islamic teachings, would only cause dire effects to the people. He writes:

"Yang kini sangat mengkhawatirkan kita ialah pencemaran (pollution) dan perusakan alam sebagai akibat dari usaha ekonomi yang hanya mencari keuntungan dan tidak mengindahkan ajaranajaran Islam. Sebab Islam memang dibuat untuk keperluan dan kepentingan manusia. Barang siapa memusuhi Islam sesungguhnya merugikan negara dan bangsa, dan merugikan dirinya sendiri. Keselamatan dunia umumnya dan Indonesia khususnya terletak dalam pengertian dan pelaksanaan ajaran-ajaran Islam dengan cara yang sebaik-baiknya (Prawiranegara, 1988: 397).

Indonesian intellectuals like Sjafruddin and Hatta, was never enthusiastic to enjoin the ideas of Islamic economics, in comparisons to their Indian Muslims counterpart in the subcontinent. One reason is that fact that their interpretation on bank interest is not equated to the usury, a common position taken by the Islamist politicians and intellectuals elsewhere. In many of his writings Sjafruddin discussed at length as to why interest should not be seen as usury. Suffice to quote here the summary of his position:

Tafsir yang salah mengenai interest yang diidentikkan dengan riba, hanya mengaburkan pandangan dan pengertian kita tentang tujuan Islam yang sebenarnya. Interest, keuntungan, baik dari dagang maupun dari pinjaman, adalah halal. Tetapi excessif profit (termasuk Excessif interest) yaitu keuntungan yang berlebihlebihan yang diperoleh dengan melanggar perikemanusiaan dan merusan alam Allah, inilah riba dan inilah yang diharamkan Allah.Riba adalah segala bentuk keuntungan yang diperoleh dengan: (a)Exploitation de l'homme par l'homme (penindasan 
dan pemerasan manusia oleh sesame manusia) dan (b) Abus de la Nature par l'homme (penyalahgunaan alam oleh manusia). Riba itu hanya dapat dicegah, kalau manusia itu tujuan hidupnya adalah mengabdi kepada Allah SWT dan berbuat baik terhadap sesam makhluk sebagaimana yang diajarkan-Nya dalam Al-Qur'an dan dijelaskan dalam hadis Nabi SAW (Prawiranegara, 1988: 406).

Another Indonesian scholar criticized the euphoria for syariah compliance banks are only obsess with the prevention of bank interest is understood as riba, while silent on the other kind of exploitative practices in the mainstream economy:

"Ekonomi Syariah direduksi dan lebih terpusatkan hanya pada upaya membangun bank-bank syariah, seterusnya riba hanya ditinjau dari segi bunga perbankan saja. Riba justru hidup subur di dalam sistem ekonomi yang eksploitatori secara luas, yang memelihara dan menumbuhkan kesenjangan ekonomi, yang membiarkan terjadinya trade-off secara sistemik untuk kerugian si miskin dan si lemah, yang subordinatif dan diskriminatori, yang membiarkan brutalitas laissez-faire dalam arti luas, yang justru diabaikan oleh mereka yang lengah oleh eforia dalam mengembangkan bank-bank syariah, tanpa memperhatikan perlunya restrukrusisasi dan dekontruksi sistem ekonomi yang usurious."

While the interest to weed out riba from the mainstream economy, there was hardly any interest to develop the ekonomi rakyat as mooted by Hatta, where the amain aim is to ensure the economic justice and welfare of the people. Why such Islamic concerns could have no interest to safeguard the people's interest? He writes

Berkaitan dengan pemikiran ekonomi koperasi yang dikebangkan Hatta, jelas terlihat pemihakannya pada ekonomi rakyat. Pemilihan ekonomi rakyat bisa dinyatakan dengan pemihakan kepada mereka yang tertindas dan teraniaya (mustadhafin). 
Mereka yang melakukan advokasi terhadap mereka yang tertindas terutama secara sistemik dan structural, jelas merupakan pahala yang besar. Tidak heran jika pemikiran-pemikiran Hatta tentang ekonomi rakyat menjadi begitu mendasar dan banyak. Istilah "ekonomi rakyat" pun adalah ciptaan Hatta (Swasono, 2010: xiv$\mathrm{xv})$.

Other Indonesian writers have written quite critically on the workings of Islamic economics, especially when the justification was made primarily on Islamic legal precepts, with utter disregards on other considerations. One write spoke on the limitations of a fiqh-based Islamic Economics:

Di bidang ekonomi, Ekonomi Islam adalah ekonomi syariah dan seterusnya. Padahal, untuk merumuskan apa itu Ekonomi Islam sebagai bidang ilmu umpamanya, perlu dirumuskan terlebih dahulu wacana ontologi, kemudian epistemologi atau metode pemahaman dan akhirnya aksiologi. Tapi hal ini tidak terjadi, sehingga ilmu-ilmu sosial Islam sebagai pengetahuan positif sulit berkembang. Para ulama mengukuhkan ilmu-ilmu normatif dengan mencarikan dasar-dasar tekstualnya. Ilmu-ilmu tersebut sudah barang tentu tidak merespons persoalan yang dihadapi oleh umat manusia dan umat Islam khususnya.Ketiganya, masuknya mekanisme "analogi yurisprudensial." ...dalam wacana Islamisme, ilmu ekonomi misalnya dikembangkan dari fikih mu'amalah. Padahal mu'amalah adalah tuntunan untuk ber-mu'amalah dalam berekonomi, terutami dalam pinjam meminjam dan perdagangan. Jadi, ekonomi bukanlah ilmu untuk memberantas kemiskinan atau untuk mencapai kemakmuran bangsa. Ternyata, fikih mu'amalah itu cakupannya terbatas dan perhatiannya terfokus kepada hukum riba (Hasanuddin, 2012: xxxv).

Another Indonesian statesman and intellectual Abdurahman Wahid puts his position more explicitly that the overall economic concern must be substantive ones, without the frenzy to be just attracted by outward 
symbolism as attached in the Islamic economics. The economic philosophy and practices as subscribed by the Indonesian state is already sufficient as long as it sticks to its fundamental, not only based on the ideals of UUD 1945 but also the premise stipulated in fiqh where: "kebijakan dan tindakan pemimpin atas rakyat yang dipimpin harus sejalan dengan kemaslahatan mereka' (tasharruf al-imam 'ala ar-raiiyah manuthun bi al-maslahah). Itu berlaku juga untuk bidang ekonomi. Ekonomi yang berorientasi kepada kemampuan berdiri di atas kaki sendiri, menjadikan ekonomi kita akan sesuai dengan ajaran-ajaran Islam (Wahid, 2006).

The proponents of Islamic economics are eager to create an alternative and to get a pie of share in the local economy. They may have been seen as trying to reap the opportunities and potentialities of the Muslim market, while insisting that their products are Islamically sanctioned. But these proponents have no other serious interest, such as the persistent problems that could be found in the mainstream economy, due to historical precedent and regressive practices as conducted by the State. The proponents themselves are close to the power establishment. As such this imposed severe limitation to this very group that is excited to promote their "alternative". Gus Dur opines:

Pengembangan teori ekonomi Islam, karena ia dikait-kaitkan dengan kekuasaan yang ada. Keadan diperparah oleh kenyataan tidak adanya peninjauan ulang terhadap kebijakan-kebijakan ekonomi pemerintah di masa lampau. Ini berarti, gagasan tentang ekonomi Islam di negeri kita, tidak pernah didasarkan atas peninjauan mendalam dari kebijakan, langkah-langkah dan keputusan-keputusan pemerintah di bidang tersebut. Bagaimana akan dibuat acuan mengenai sebuah sistem ekonomi Islam, kalau fakta-fakta ekonomi dan finansial semenjak kita merdeka tak pernah ditinjau ulang? (Wahid, 2006: 198). 
To Gus Dur, whether the economy is called "Islamic" or otherwise, it would not matter. "Apakah ekonomi yang sedemikian itu akan dinamai ekonomi Islam atau hanya disebut ekonomi nasional saja, tidaklah relevan untuk didiskusikan disini. Yang terpenting, bangunan ekonomi yang dikembangkan, baik tatanan maupun orientasinya, sesuai dengan ajaran Islam. Penulis yakin, ekonomi yang sedemikian itu juga sesuai dengan ajaran-ajaran berbagai agama lain. Karenanya, penamaan ekonomi seperti itu dengan nama ekonomi Islam, sebenarnya juga tidak diperlukan sekali, karena yang terpenting adalah pemberlakuannya, dan bukan penamaannya." (Wahid, 2006: 163). The idea of Islamic economics to him is bereft of deep intellectual rigour and systemisation, but piecemeal advocacy, often not grounded to the needs and urgencies of the present (Wahid, 2006: 199). He continues, explaining modestly that the current market system would not be in contradiction to Islam as long as there are mechanism in which the poor are protected by the State instrument and intervention:

Mekanisme yang digunakan untuk mencapai kesejahteraan itu, tidak ditentukan format dan bentuknya. Dengan demikian, acuan persaingan-perdagangan bebas dan efisiensi yang dibawakan oleh kapitalisme, tidaklah bertentangan dengan pandangan ekonomi yang dibawakan Islam. Bahkan Islam menganjurkan adanya sikap fastabiqu al-khairat (berlomba dalam kebaikan), yang menjadi inti dalam praktek ekonomi yang sehat. Dengan persaingan dan perlombaan, akan terjadi efisiensi yang semakin meningkat. Namun, pemerintah sebagai penguasa harus memberikan perlindungan kepada yang lemah tanpa melakukan intervensi dalam perdagangan. Negara-negara yang berteknologi maju-pun melindungi para penganggur, sampai 3\% dari jumlah keseluruhan kaum pekerja. Ini adalah prinsip yang harus dipegang teguh dalam menentukan kebijakan ekonomi.

For those that clamour for Islamic economics, especially Islamic banking, Gus Dur cautious the readers that after all it is capitalistic 
venture, although selected Islamic principles are applied. This seems to be a disjuncture since "orientasi kapitalistik itu dapat dibedakan dari orientasi Islam. Dalam orientasi kapitalistik yang diutamakan adalah individu pengusaha besar dan pemilik modal. Dalam Islam, justru kepentingan rakyatkesejahteraan masyarakat secara keseluruhan yang menjadi ukuran" (Wahid, 2006: 166-167).

Gus Dur criticised the State's initiatives in establishing bank syariah, where the interest are often due to ignorance to the Islamic message itself where the propensity to see an institutionalised Islamic forms supersede the tendency to see Islam manifest via culturalforms.

Bukankah bank seperti itu menyatakan tidak memungut bunga bank (interest) tetapi menaikkan ongkos-ongkos (bank cost) di atas kebiasaan? Bukankah dengan demikian, terjadi pembengkakan ongkos yang tidak termonitor, sesuatu yang berlawanan dengan prinsip-prinsip cara kerja sebuah dengan bank yang sehat. Lalu, bagaimanakah halnya dengan transparansi yang dituntut dari cara kerja sebuah bank agar biaya usaha dapat ditekan serendah mungkin.Karenanya, banyak bank-bank swasta dengan para pemilik saham non-Muslim, turut terkena "demam syari'atisasi" tersebut. Hal itu disebabkan kurangnya pengetahuan mereka tentang hukum Islam tersebut (Wahid, 2006).

In many Muslim societies today, there are enormous interests to establish Islamic institutions, ranging from Islamic state to Islamic economics. Gus Dur saw this tendency as unnecessary. Islamic institution such as Islamic banks is no guarantee that Islamic principles and values are substantively subscribed and adhered to. He opines:

"Kalau kita mementingkan budaya/kultur, maka lembaga yang mewakili Islam tidak harus dipertahankan mati-matian, seperti partai Islam, pesantren dan tentu saja bank syariah. Selama budaya Islam masih hidup terus, selama itu pula benih-benih berlangsungnya cara hidup Islam tetap terjaga. Karena itu, kita 
tidak perlu berlomba-lomba mengadakan syariatisasi, bahkan itu dilarang UUD 1945 jika dilakukan oleh pihak pemerintah dan lembaga-lembaga negara. Mudah dikatakan, namun sulit dilaksanakan bukan? (Wahid, 2006: 194-195).

Proponents of Islamic economics must be made to see that the operation of the modern economy is not simply linked to interest which they averse strongly. The fundamentals of economy which ensure the economic pie to be shared justly must be overall concerns. Consistent rethinking of various propositions of Islamic economics must be made, and to be made known to the larger Muslim public. The religious garb of the proponents must be scrutinized especially when such garb distracts the fundamental criteria of running an economy. If the system only produces inefficiency, high cost and deny access to the general population, then it cannot hide behind the religious sanctions. This requires a critical discourse, and it should form part of its discursive repertoire, rather than remaining outside it.

In all, the defects, irregularities and limitations of the Islamic economics must be address. The mainstream economic discourse must also seriously give attention to this propositions and assertions. Kuran sees the need to overcome this impasse which

requires an arduous two-pronged strategy of economic development and cultural repair. Out of both compassion and self-interest, the developed countries must take steps to assist the Islamic world in ways that go beyond window dressing. For starters, the United States and the European Community should lift barriers to the industrial and agricultural exports of the Islamic countries, especially the poorest. Equally important, the development the developed world must lend a helping hand to the secular education systems of the Middle East and South Asia. Within the Islamic world itself, governments and civil organizations can join the struggle through a dual program of 
their own. Making a renewed and credible commitment to poverty reduction, they must also be willing to counter the nonsensical and destructive elements of Islamist discourse. Regardless of their faith or creed, the world's intellectuals can also help out by abandoning the relativist strains of modern multiculturalism. Although all major cultures, including those associated with Islam, offer much that is valuable and instructive, they are not equally successful at producing viable economic solutions. In particular, whatever other comforts Islamism gives its adherents, it is clearly an inferior instrument of economic development. In fact, some of its variants, including that of Taliban, have proven to be positively harmful, even hostile, to material prosperity. The laudable goal of cherishing the achievements of diverse cultures and respecting cultural differences does not absolve us of the responsibility to acknowledge failures, dead-ends, and dangers where they are noticed (Kuran, 2015).

\section{Conclusion}

Hence a celebratory scholarship is not sufficient or to remain as only observers and leaving the justifications of Islamic economics to its experts, with the notion that they know best of the Islamic precepts in the economic realms. We must scrutinize the working of Islamic economics as we have scrutinized critically on capitalism, socialism and mixed economy, democracy, feudalism and other system of ideas. Obviously, no exception should be given to the ideas and practices of Islamic economics. To those who hide behind the Islamic teachings to buttress their own economic interests, or for maintain their cultural-religious agenda must be exposed and engaged. 


\section{References}

Aboulaich, R., Boularhmane, I., Moumen, S.E. (2017). Cost of Capital Model Based on Islamic Finance Principles. International Journal of Applied Business and Economic Research 15 (5), pp. 539-550.

Ahmad, A.Y. (2017). The Role of Money in Financial Instability and Possibilities of Reformation within an Islamic Financial System. Journal of King Abdulaziz University, Islamic Economics 30 (3), pp. 187-208.

Al Basri, Abu Uthman Amr Ibn Bahr Al-jahiz. (2012). The Book of Insight Into Commerce translated by Adi Seti, Kuala Lumpur: Percetakan Mesbah Sdn Bhd.

Al-Attas, Muhammad Naquib. (2007). The ICLIF Leadership CompetencyModel (LCM): An Islamic Alternative, Kuala Lumpur: Percetakan Mesbah Sdn. Bhd.

Al-Syaybani. Al-Imam Muhammad Ibn Al-Hasan. (2011). The Book of Earning a Livelihood translated by Adi Setia, Kuala Lumpur: Percetakan Mesbah Sdn Bhd.

Arzayeva, M., Supugaliyeva, G.I., Zamanbekov, D., Kokeyeva, D. Islamic Finance in a Global Context. Man in India 97 (2), pp. 229-238.

Ayubi, Nazih. Political Islam; Religion and Politics in the Arab World. New York: Routledge, 1994.

Behdad, Sohrab. "A Disputed Utopia: Islamic Economics in Revolutionary Iran," in Comparative Study of Society and History, 1994, pp. 775-813

Boediman, E.P. (2017). Halal Lifestyle in Marketing Communication of Tourism and Hospitality. International journal of Economic Research 14 (4), pp. 429-438.

Buehler, M., Muhtada, D. (2016). Democratization and the Diffusion of Shari'a Law: Comparative Insight from Indonesia. South East Asia Research 24 (2), pp. 261-282. 
Dzutsati, V., Siroky, D., Dzutsev, K. (2016). The Political Economy of Support for Sharia: Evidence from The Russian North Caucasus. Politics and Religion 9 (4), pp. 965-719.

Ebrahim, M.S., Sheikh, M. (2017). Debt Instruments in Islamic Finance: A Critique. Arab Law Quarterly 30 (2), pp. 185-198.

Gouda, M. (2016). Stealing More is Better? An Economic Analysis of Islamic Law of Theft. European Journal of Law and Economics 42 (1), pp. 103-128.

Goulet, Dennis. (2002). "Ethical Analysis in Development Economics," Crossing the Mainstream edited by Amitava K. Dutt and Kenneth P. Jameson, Indiana: University of Notre Dame Press.

Ismail, Zaidi \& Badron, Sani. (2012). Good Governance Adab-Oriented Tadbir in Islam. Kuala Lumpur: Institut Kefahaman Islam Malaysia.

Jomo K. S. (1977). "Islam and Weber: Rodinson on The Implications of Religion for Capitalist Development" in The Developing Economies, Vol.17, No.3, September, pp. 240-250.

Jomo K. S. (ed.). (1992). Islamic Economic Alternatives; Critical Perspective and New Directions, Kuala Lumpur: Macmillan.

Khan, Muhammad Akram. "Islamic Economics: The State of the Art," in The American Journal of Islamic Social Sciences, Vol. 16, No.2, pp. 89-104.

Khoo Khay Jin. "Teaching Islamic Economic Thought: Some Comments," in Ilmu Masyarakat, Vol.17, pp 13-16

Kuran, Timur. (1983). "Behavioral Norms in the Islamic Doctrin of Economics," Journal of Economic Behavior and Organization, Vol.4, pp 353-379

Kuran, Timur. (1989). "On the notion of Economic Justice in Contemporary Islamic Thought," International Journal Middle East Studies, Vol. 21, pp 171-191

Kuran, Timur. (1994). "Religious Economics and the Economics of Religion," in Journal of Institutional and Theoritical Economics, Vol.4, 
No. 150, pp 769-775.

Kuran, Timur. (1995). "Islamic Economics and the Islamic Subeconomy," Journal of Economic Perspectives, Vol. 9, No. 4, pp 155-173

Kuran, Timur. (2010). Islam and Mammon: The Economic Predicaments of Islamism. Princeton: Princeton University Press.

Kuran, Timur. (2015). “The Religious Undercurrents of Muslim Economic Grievances," in Social Science Research Council, pp 1-5

Listyaningsih, E., Krishnamurti, C. (2017). The Impact of Global Financial Crisis on Jakarta Islamic Index (JII): A Tranding Volume Perspective. Advanced Science Letters 23 (9), pp. 8197-8203.

Malik, M Luthfi. (2013). Etos Kerja, Pasar, dan Masjid, Jakarta: LP3ES.

Mas'udi, Masdar F. (1991). Agama Keadilan, Jakarta: Pustaka Firdaus.

Maurer, Bill. (2001). "Speculations on Islamic Financial Alternatives," in Anthropology Today, Vol. 17, No.3, June, pp 27-29

Metwally, M.M. (1997). "Economic Consequences of Applying Islamic Principles in Muslim Societies" in International Journal of Social Economics, Vol. 24, No. 7/8/9, pp.941-957.

Nasr, Sayyed Vali Reza. "Towards a Philosophy of Islamic Economics," in the Muslim World, pp 175-196

Nasr. Sayyed Vali Reza. (1989). "Islamic Economics: Novel Perspectives," in Middle Eastern Studies, Vol. 25, No. 4, October 1989, pp 516-530

Nasr. Sayyed Vali Reza. (2009). The Rise of Islamic Capitalism, New York: Free Press, 2009.

Nienhaus, Volker. "Islamic Economics: Dogma or Science?” in The World and the West; an Introdcution to Political Cultures and International Relations edited by Kai Hafez, Leiden: Brill, 2000, pp 87-99

Philipp, Thomas. (1990). "The Idea of Islamic Economics" in Die Welt des Islam, Vol. 30, 1990, pp. 117-139.

Prasetyo, Eko. (2002). Islam Kiri Melawan Kapitalisme Modal dari Wacana Menuju Gerakan; Yogyakarta: Insist Press. 
Prasetyo, Eko. (2003). Islam Kiri; Jalan Menuju Revolusi Sosial. Yogyakarta: Insist Press.

Prasetyo, Galih. (2015). Indonesia Dalam Cengkeraman Liberalisme. Jakarta: Penerbit Koekoesan.

Prawiranegara, Sjafruddin, (1988). Ekonomi dan Keuangan; Makna Ekonomi Islam; Kumpulan Karangan Terpilih Jilid II, Jakarta: Pustaka Jaya.

Prawiranegara, Sjafruddin. (2011). Ekonomi dan Keuangan; Makna Ekonomi Islam. Jakarta: Pustaka Jaya.

Presley, John R. and Sessions, John G. "Islamic Economics: The Emergence of a New Paradigm," in The Economic Journal, Vol 104, 1994, pp 584596

Ragab, Ibrahim A. (1980). "Islam and Development” in World Development, Vol.8, pp. 513-521.

Rahardjo, Dawam. (2016). Ekonomi Neo-Klasik dan Sosialisme Religius; Pragmatisme Pemikiran Ekonomi Politik Sjafruddim Prawiranegara. Jakarta Selatan: Mizan Publika.

Rahardjo. Dawam. (1999). Masyarakat Madani: Agama, Kelas Menengah dan Perubahan Sosial, Jakarta: Pustaka LP3ES.

Rahardjo. Dawam. (2002). Islam dan Transformasi Budaya. Yogyakarta: Dhanabakti.

Rahardjo. Dawam. (2010). Merayakan Kemajemukan, Kebebasan dan Kebangsaan. Jakarta: Prenada Media Group.

Rahardjo. Dawam. (2012). Kritik Nalar Islamisme dan Kebangkitan Islam. Jakarta: Freedom Institute.

Rahman. Fazlur. (1964). "Riba and Interest" in Islamic Studies, Vol.3, No.1, March, pp 1-43

Ridwan, Nur Kholik. (2002). Islam Borjuis dan Islam Proletar; Kontruksi Baru Masyarakat Islam Indonesia, Yogyakarta: Galang Press.

Robinson, Robert V. "The Egalitarian Face of Islamic Orthodoxy: Support for Islamic Law and Economic Justice in Seven Muslim-Majority 
Nations," in American Sociological Review, Vol. 71, 2006, pp. 167-190 Rodinson, Maxime. (2007). Islam and Capitalism, London: Saqi Books. Roy, Oliver. "The Islamic Economy: Between Illusions and Rhetoric," in The Failure of Political Islam translated by Carol Volk, Cambridge: Harvard University Press, 1994, pp 132-145

Salehin, M.M. (2016). Islamic NGOs in Bangladesh: Development, Piety and Neoliberal Governmentaly, pp. 1-216.

Sardar, Ziauddin, (1996). "Beyond Development: an Islamic Perspective," in The European Journal of Development Research, Vol. 8, No. 2, pp. 36-55.

Serageldin, Ismail. "The Muslim World and The Challenges of Sustainable Development" in Forum Ilmiah Festival Istiqlal II, pp 171-197

Siddiqi, Akhtar Hussain. (1984). "Muslim World: Its Dilemma of Development," in Journal of South Asian and Middle Eastern Studies, Vol. 7, No.3, pp.63-68

Soedomo, Sudarsono (2012). Menyambut Indonesia Baru; Obrolan Nusantara, Bogor: Firdaus Press.

Sukidi. (2006). "Max Weber's Remarks on Islam: The Protestant Ethic among Muslim Puritans," in Islam and Christian-Muslim Relations, Vol. 17, No. 2, April, pp. 195-205.

Sutcliffe, Claud R. (1975). "Is Islam an Obstacle to Development? Ideal Patterns of Belief versus Actual Patterns of Behavior", The Journal of Developing Areas, Vol.10, No.1, October, pp 77-82.

Wahid, Abdurrahman dkk. (2000). Islam Sosialisme \& Kapitalisme. Yogyakarta: Madani Press.

Wilson, Loretta S. and Kwilecki, Susan. (1999). "Economics and Religion; A Bridge Too Far," in College Teaching, Vol. 48, No.4, March, pp $147-$ 150 
Vol. 2 No. 2, May - August 2017 


\section{Shirkah Author Guidelines}

Shirkah currently offers two routes to submit manuscripts. We highly recommend to submit the articles which are made using OJS (Open Journal System). Feel free register as author soon through visiting http:// shirkah.or.id/index.php/home/user/register. The authors may directly send their manuscripts, along with their resume, to shirkahiainsurakarta@ gmail.com. Please prepare your manuscripts, using following guidelines:

1. Manuscript must be written in English. Submitted articles should not have been published or be under review for publication with another journal.

2. Manuscript's length is about $15-20$ pages, typed in one-half spaced on A4-paper size.

3. Manuscript must include an $150-200$ word abstract and keywords.

4. Manuscript must be arranged as follows: Title, Name of Author, E-mail address, Abstract, Keywords, Introduction (including method if any), Discussion, Conclusion, References.

5. Manuscript's titles not more than ten words.

6. Manuscript must be submitted in Microsoft Word or RTF.

7. Arabic words should be transliterated according to the style of International Journal of Middle Eastern Studies.

8. Manuscript references are preferably derived from the up-to-date references.

9. The author's resume should be submitted separately, consisting of at least full name, institutional address, phone number, areas of studies, and recent publications (if any).

10. Shirkab use APA Style 6th edition (2010) as reference format writing. We suggest the use of a reference manager software such as Mendeley, Zotero, and Endnote at templating the citation style. APA Style to be used is as follows: 


\section{Book with single author}

Swann, G. M. Peter. (2014). The Economics of Innovation an Introduction. Cheltenhum \& Northampton: Edward Elgar.

in-text citation: (Swann, 2014)

\section{Articles in reference books}

Alatas, S. F. (2006). Islam and the Science of Economics in Abu Rabi', I.M. The Blackwell Companion to Contemporary Islamic Thought. USA: Willey-Blackwell (pp. 587-606).

in text citation: (Alatas, 2006)

\section{E-Book}

Hackett, Rosalind (2007). "Religous Dimentions of War and Peace: Introduction.” Dalam Gerrie ter Haar dan Yoshio Tsuruoka (Ed.), Religion and Society: An Agenda for the 21st Century (h. 3-6). Retrieved from http:// brill.nl.

in text citation: (Hackett, 2006)

\section{Master's thesis, from a commercial database}

McNieI, D. S. (2006). Meaning through narrative: A personal narrative discussing growing up with an alcoholic mother (Master's thesis). Available from ProQuest Dissertations and Theses database. (UMI No. 1434728)

in text citation: (Mc Niel, 2006)

\section{Doctoral dissertation, from an institutional database}

Adams, R. J. (1973). Building a foundation for evaluation of instruction in higher education and continuing education (Doctoral dissertation). Retrieved from http://www.ohiolink.edu/etd/

in text citation: (Adams, 1973) 


\section{Doctoral dissertation, from the web}

Bruckman, A. (1997). MOOSE Crossing: Construction, community, and learning in a networked virtual world for kids (Doctoral dissertation, Massachusetts Institute of Technology). Retrieved from http:/www-static. cc.gatech.edu/--asb/thesis/

in text citation: (Bruckman, 1997)

\section{Journal article with No DOI}

Bourkhis, K., and Nabi, M. S. (2013). Islamic and conventional banks' soundness during the 2007-2008 financial crisis. Journal Metrics, 22(2), 68-77.

in-text citation: (Bourkhis \& Nabi, 2013).

\section{Journal article with DOI}

Ichwan, M. (2012). The Local Politics Of Orthodoxy: The Majelis Ulama Indonesia in the Post-New Order Banten. Journal Of Indonesian Islam, 6(1), 166-194. doi:http://dx.doi.org/10.15642/JIIS.2012.6.1.166-194

In text citation : (Ichwan, 2012)

\section{Abstract as citation}

Hasan, N. (2012). Islamist Party, Electoral Politics And Da'wah Mobilization Among Youth : The Prosperous Justice Party (PKS) in Indonesia. Journal of Indonesian Islam, 6(1), 17-47. Abstract from http:// jiis.uinsby.ac.id/index.php/jiis/article/view/97

in text citation : (Hasan, 2012)

\section{Mass media article}

Sahal, Akhmad (2014, March 2). Kiai Sahal dan Realisme Fikih.Tempo Magazine, p. 120.

in text citation : (Sahal, 2014) 


\section{Research report}

Fisher, B. S., Cullen, F. T., \& Turner, M. G. (2000). The Sexual Victimization of College Women. Research Report.

in text citation : (Fisher, Cullen, Turner, 2000)

\section{Monograph}

Routray, Bibhu Prasad (2013), National Security Decision-Making in India (RSIS Monograph No. 27). Singapura: Rajaratnam School of International Studies.

in text citation : (Routray, 2013)

\section{Proceeding article}

Sudibyakto, Hizbaron, D.R., \& Jati, R (Ed.) (2009), Proceeding International Seminar Disaster Theory, Research and Policy. International seminar held by Sekolah Pascasarjana, Universitas Gajahmada, Yogyakarta, 8-9 Desember 2009.

in text citation : (sudibyakto and Jati, 2009)

\section{Paper conference/seminar/symposium}

Janutama, Herman Sinung (2011). "Kraton dan Hubungan Antar Agama." Paper presented in Seminar Kraton dan Panatagama held by Center for the Study of Islam and Social Transformation (CISForm), Yogyakarta, 17 November.

in text citation :(Janutama, 2011)

\section{Online article in web}

Shiva, (2006, February). Bioethics: A Third World Issue. Native-web. Diperoleh dari http://www.nativeweb.org/ pages/legal/shiva.html

in text citation : (Shiva, 2006) 


\section{Online research report}

Kessy, S. S. A., \& Urio, F M. (2006). The contribution of microfinance institutions to poverty reduction in Tanzania (Research Report No. 06.3). Retrieved from Research on Poverty Alleviation website: http://www. repoa.or.tz /documents_storage/Publications/Reports/06.3_Kessy_and_ Urio.pcif

in text citation : (kessy and urion, 2006)

\section{Holy book}

Qur an, $2(25)$

In text citation : (Q. al-Baqarah 2:25).

\section{Encyclopaedia}

Graycar, Adam (1992). Social Welfare Policy. Dalam Mary Hawkesworth dan Maurice Kogan (Ed.), Encyclopedia of Government and Politics (Vol. 1). London: Routledge.

in text citation : (Graycar, 1992)

\section{Interview}

Sultan Hamengkubuwono X (interview, 2011, April 19)

in text citation: (Hamengkubuwono, 2011)

\section{Documentary film}

Steijlen, Fridus (2008). A Day in the Life of Indonesia [documentary film, 58 minutes]. Leiden: KITLV Press.

in text citation : (Steijlen, 2008) 
Vol. 2 No. 2, May - August 2017 